\title{
Studying the Efficiency of Treatment Model Mixtures of Petroleum Products with the Modified Sorbent Made of Ash-and-Slag During Dynamic Sorption
}

\author{
Tatyana Germanovna Korotkova1*, Svyatoslav Andreevich Bushumov', \\ Svetlana Yurevna Ksandopulo' ${ }^{1}$, Nataliya Vladimirovna Solonnikova ${ }^{1}$ \\ 1 Kuban State Technological University, Moskovskaya Street, 2, Krasnodar, 350072, Russian Federation \\ * Corresponding author's e-mail: tatyana.korotkova.asu@bk.ru
}

\begin{abstract}
Experimental studies on the dynamic sorption of model mixtures containing petroleum products were performed. The subject of the study was the modified sorbent from the ash-and-slag wastes accumulated in the ash dump of the Novocherkassk State District Power Plant (SDPP) (Russia, Novocherkassk, Rostov Region), obtained using the method of ash removal. The quantity of the sorbent for each model solution was fixed at $5.0 \mathrm{~g}$. The model solutions in the amount of $1 \mathrm{dm}^{3}$ were passed through a column filled with the modified sorbent at constant filtration rate $w=$ const with filtrate takeout of $0.1 \mathrm{dm}^{3} / \mathrm{min}$. The $\mathrm{pH}$ value of the solution, which is advisable for extracting petroleum products, was determined experimentally. For this purpose, the model solutions, containing $100 \mathrm{mg} / \mathrm{dm}^{3}$ of petroleum products with $\mathrm{pH}=1.65,4.01,6.86,8.12,9.18$, and 11.34 , were prepared. The optimum $\mathrm{pH}$ value of the solution was considered $\mathrm{pH}=7.5$. The content of petroleum products in the filtrate in all experiments was determined using IR spectrometry. The working range of water pollution with petroleum products was determined on a series of model solutions containing petroleum products in the range between 0.5 and $10 \mathrm{mg} / \mathrm{dm}^{3}$ with the increment of 0.5 , between 10 and $100 \mathrm{mg} / \mathrm{dm}^{3}$ with the increment of 10 , and between 100 and $1,000 \mathrm{mg} / \mathrm{dm}^{3}$ with the increment of 100 . The maximum extraction of petroleum products from the solution was $88.23 \%$. The applicability of the Henry's law to the range of petroleum products concentrations in the filtrate of $50 \mathrm{mg} / \mathrm{dm}^{3} \mathrm{was}$ confirmed. The adsorption equilibrium constant (Henry's law constant) was determined experimentally. The effect of the natural freshwater matrix on the degree of petroleum products extraction was studied; no significant effect on petroleum products sorption was found. A conclusion was made that the sorbent can ensure the efficiency of water purifying from petroleum products of no less than $85 \%$ in the range of pollution between 5 and $300 \mathrm{mg} / \mathrm{dm}^{3}$.
\end{abstract}

Keywords: ash-and-slag, thermal power plant, sorbent, sorption dynamics, the efficiency of petroleum products extraction

\section{INTRODUCTION}

Fly ash and ash-and-slag, called together ashand-slag wastes (ASW), or simply ash-and-slag, are the large-scale wastes of thermal power plants that use solid fuel (coal). Huge areas - ash dumps (ash-and-slag waste dumps) - are used for their storage. ASW are mainly transported to the ashand-slag waste dumps with buger pumps after mixing ASW with water. As a result, water pulp is formed. This method of waste transportation is called hydraulic ash disposal (HAD).
In Russia, the amount of accumulated ashand-slag waste is equal to billions of tons, and the area occupied by them reaches thousands of hectares of land [Cherentsova, 2013]. Many works were devoted to using ASW as an adsorbent in wastewater treatment for removing phosphates, heavy metals, organic pollutants, phenols, and dyes [Cheung, Venkitachalam, 2000; Safaa, 2013; Yamada et al., 1986; Dabi, Patwa, 2015]. It was suggested to use ASW as an adsorbent for treating the wastewater contaminated with petroleum products [Shishelova et al., 2008]. The studies 
on the ASW hazard class at the Novocherkassk SDPP performed by the authors showed that the dry ash and slag hazard class for the environment was between III and IV (low-hazard) [Korotkova et al., 2017, Bushumov et al., 2018]. The ash and slag accumulated at ash dumps through HAD belong to the environmental hazard class V (virtually not hazardous) [Korotkova et al., 2018].

This work is devoted to studying the adsorbent obtained by modifying the ASW from the Novocherkassk SDPP accumulated at dumps by hydraulic ash disposal for removing the oil products from wastewater. Dynamic sorption was performed by means of model solutions with various concentrations of petroleum products acting as wastewater.

\section{RELATED WORK}

The use of adsorbents for extracting components from solutions has been known since the ancient times. Fundamental theoretical generalizations have been developed: theory of thermodynamics of adsorption, the fundamentals of calculating the adsorption and desorption kinetics, and the theory of mass transfer in adsorption processes [Keltsev, 1984].

Sorbents of natural (natural organic materials) and synthetic origin (synthetic organic materials), as well as sorbents with properties changed by modification, e.g., adding a component, grinding, or calcination at high temperatures, are used to remove the petroleum products from the water. Such sorbents are called petroleum sorbents. In wastewater, the petroleum products are contained in free, emulsified, and dissolved states. The mechanisms for removing petroleum products are physical surface adsorption and bulk adsorption (absorption by the entire volume of the sorbent) [Veprikova et al., 2010].

The sorbent efficiency is assessed by sorbent petroleum capacity under the dynamic conditions by passing the polluted solution through a compacted layer of the sorbent in a column until the complete saturation of the sorbent [Komissarenkov, Fedorova et al., 2015]. Adsorption equilibrium, which allows determining the amount of the sorbent (or the thickness of the adsorptive layer) required for the maximum possible efficiency of solution treatment is also an important characteristic [Keltsev, 1984, Makarevich, Bogdanovich, 2015]. Various kinetic models are studied to understand and explain the mechanism of adsorption [Gorme et al., 2010].
In this work, the dynamics of sorption of the model solutions containing petroleum products were studied. The efficiency of extracting petroleum products by means of a modified sorbent made of the ASW from the Novocherkassk SDPP accumulated by hydraulic ash disposal was studied.

\section{METHODS}

The content of petroleum products in the filtrate was determined by means of IR spectrometry with PCM-025 concentration meter ( $\mathrm{P}$ - petroleum products), and double-checked using PC-3 concentration meter to remove random measurement errors according to environmental regulatory document of the federal level (ERD F) 14.1:2:4.5-95. The studied amounts of filtrates were placed in a $2 \mathrm{dm}^{3}$ separating funnel; diluted sulphuric acid was added at the rate of $2 \mathrm{~cm}^{3}$ of acid per $100 \mathrm{~cm}^{3}$ of the filtrate. The vessel in which the filtrate was held was rinsed with $10 \mathrm{~cm}^{3}$ of carbon tetrachloride, which was later drained into a separating funnel. Another $20 \mathrm{~cm}^{3}$ of carbon tetrachloride were added to the filtrate, and extraction was performed with vigorous stirring for four minutes. Afterwards, the emulsion was left to settle for 10 minutes. The organic layer was drained into a $100 \mathrm{~cm}^{3}$ measuring cylinder and the extract was dehydrated with $5 \mathrm{~g}$ of anhydrous sodium sulfate until it lightened up, followed by decanting of the extract into a $50 \mathrm{~cm}^{3}$ measuring cylinder in order to determine the exact volume. Next, the extract was passed in a chromatography column through a layer of activated aluminum oxide for removing the interfering polar compounds and residual water. The prepared extract was placed in a cuvette of a concentration meter for subsequent detection of $\mathrm{C}-\mathrm{H}$ bonds in the area of IR radiation, with the aim of obtaining the analytical signal that characterized the quantitative content of the studied components.

\section{RESULTS AND DISCUSSION}

The object of the study was the modified sorbent obtained from ASW of the Novocherkassk SDPP, accumulated at ash dumps by hydraulic ash disposal. The waste was formed by burning coal of the Donetsk culm. The sorbent was obtained in two stages by heating and exposure: in the first 
stage, the ash-and-slag waste was heated to $110^{\circ} \mathrm{C}$ and kept at this temperature for 30 minutes; in the second stage, it was heated to $600^{\circ} \mathrm{C}$ and kept at this temperature for 40 minutes. These stages allowed to increase the internal pore volume and to obtain the modified sorbent. The physicochemical properties of the sorbent were experimentally determined by the authors: bulk density of $0.666 \mathrm{~g} / \mathrm{cm}^{3}$; ash content of $99.5 \%$; abrasion of $8.5 \%$; specific pore volume of $0.506 \mathrm{~cm}^{3} / \mathrm{g}$, and sorption capacity of $0.56 \mathrm{~g} / \mathrm{g}$.

The optimum $\mathrm{pH}$ value of the solution which is advisable for extracting petroleum products was determined beforehand. The model solutions, containing $100 \mathrm{mg} / \mathrm{dm}^{3}$ of petroleum products with $\mathrm{pH}=1.65,4.01,6.86,8.12,9.18$, and 11.34 , were prepared. The model solutions with calibrated content were prepared on the basis of the standard sample of the composition of petroleum products solution in carbon tetrachloride by state standard samples 7822-2000 (Russia). The solutions used for maintaining a certain $\mathrm{pH}$ value were prepared on the basis of the standard titers for preparing buffer solutions of operational $\mathrm{pH}$ standards of the 3 rd class standard captions (SC) SC-pH-04.3 (Russia) in accordance with state industry standard (SIS) SIS 8.135-2004 (Russia). The model solutions in the amount of $1 \mathrm{dm}^{3}$ were passed through a column filled with the modified sorbent (Figure 1). The quantity of the sorbent for each model solution was fixed at $5.0 \mathrm{~g}$. The inner diameter of the column was $12.5 \mathrm{~mm}$, and the thickness of the sorbent layer was $61.2 \mathrm{~mm}$. The experiments on $\mathrm{pH}$ optimization were performed at constant filtration rate $w=$ const with filtrate takeout of $0.1 \mathrm{dm}^{3} / \mathrm{min}$. The content of petroleum products in the filtrate was determined by means of IR spectrometry on the PCM-025 concentration meter.

The efficiency of petroleum products extraction was determined as the ratio of the mass of petroleum products trapped by the sorbent to the weight of petroleum products in the initial

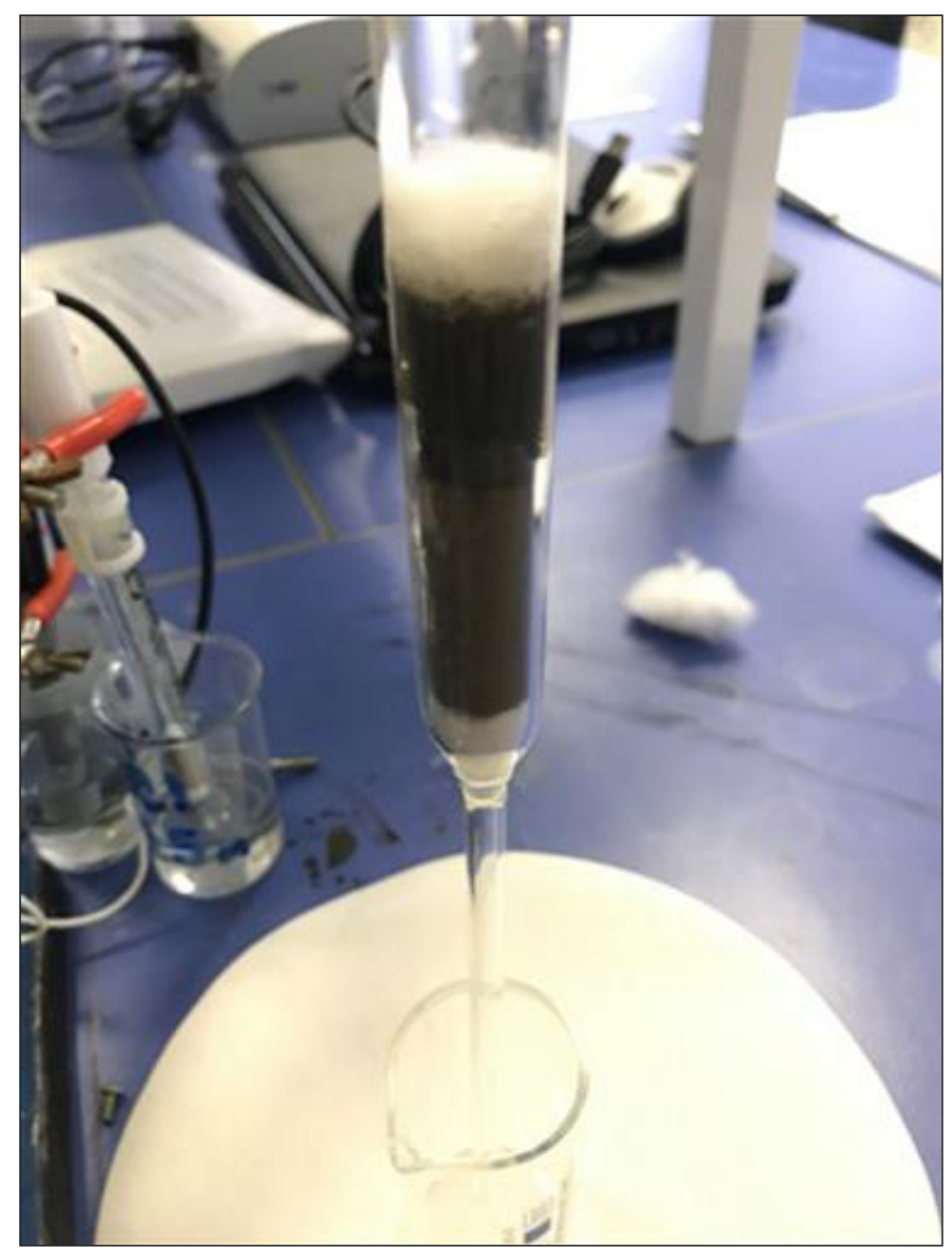

Figure 1. The column filled with the modified sorbent 
solution, expressed as a percentage. For this purpose, the following material balance was made:

$$
\begin{gathered}
V=V_{f}+V_{s} \\
V C=V_{f} C_{f}+V_{s} C_{s}
\end{gathered}
$$

where $V$ was the volume of the initial solution, $V=1 \mathrm{dm}^{3}$ (const);

$C$ was the concentration of petroleum products in the initial solution, $C=100 \mathrm{mg} / \mathrm{dm}^{3}$ (const);

$V_{f}$ was the volume of the filtrate, $\mathrm{dm}^{3}$;

$C_{f}$ was the concentration of petroleum products in the filtrate, $\mathrm{mg} / \mathrm{dm}^{3}$ (by concentration meter);

$V_{s}$ was the pore volume in the sorbent, $\mathrm{dm}^{3}$; and

$C_{s}$ was the concentration of petroleum products in the sorbent, $\mathrm{mg} / \mathrm{dm}^{3}$.

The pore volume in the sorbent $V, \mathrm{dm}^{3}$ is determined by multiplying the specific pore volume $v, \mathrm{dm}^{3} / \mathrm{g}$ by the weight of the weighed amount of the sorbent $m$, expressed in $\mathrm{g}$ :

$$
V_{S}=v m=0.506 \cdot 5 / 1000=2.53 \cdot 10^{-3}
$$

The volume of the filtrate $V_{f}, \mathrm{dm}^{3}$, is found from the overall material balance (1):

$$
V_{f}=V-V_{s}=1-2.53 \cdot 10^{-3}=0.99747
$$

From the petroleum products material balance (2), the concentration of petroleum products in the sorbent $C_{s}, \mathrm{mg} / \mathrm{dm}^{3}$ was determined. The experimental and calculated data are shown in Table 1.

Figure 2 shows the obtained dependence of the efficiency of extracting petroleum products on the $\mathrm{pH}$ value of the solution. In the further experimental studies, $\mathrm{pH}=7.5$ was adopted.

In order to determine the working range of water pollution with petroleum products, a series of model solutions were prepared, containing the petroleum products in the range between 0.5 and $10 \mathrm{mg} / \mathrm{dm}^{3}$ with the increment of 0.5 , between 10 and $100 \mathrm{mg} / \mathrm{dm}^{3}$ with the increment of 10 , and between 100 and $1,000 \mathrm{mg} / \mathrm{dm}^{3}$ with the increment of 100. Similarly as in the previous experiment, the quantity of the sorbent for each model solution was fixed at $5.0 \mathrm{~g}$. The model solutions in the amount of $1 \mathrm{dm}^{3}$ were passed through a column filled with the modified sorbent at a constant filtration rate $w=$ const with filtrate takeout of $0.1 \mathrm{dm}^{3} / \mathrm{min}$. The content of petroleum products in the filtrate was determined by means of IR spectrometry on the PCM-025 concentration meter. The efficiency of petroleum products extraction was determined in a similar way using expressions (1) - (4). The experimental and calculated data are shown in Table 2. The maximum extraction of petroleum products from the solution was $88.23 \%$. Figure 3 shows the dependence of petroleum products extraction efficiency in \% on the concentration of petroleum products in the solution $C \mathrm{mg} / \mathrm{dm}^{3}$, in a logarithmic system of coordinates by abscissa $\mathrm{X}$-axis. While analyzing this dependence, one can draw a conclusion that the sorbent can ensure $85 \%$ efficiency of removing the petroleum products from the wastewater in the range of pollution between 5 and $300 \mathrm{mg} / \mathrm{dm}^{3}$.

The analysis of the data in Table 2 shows that when the concentration of petroleum products in the solution $C$ increases, the concentration of petroleum products in the sorbent $C_{s}$ and in the filtrate $C_{f}$ increases as well. Simultaneously, the ratio of petroleum products concentration in the sorbent to the concentration of petroleum products in the filtrate increases to a certain limit (maximum) value (Figure 4, logarithmic system of coordinates by $\mathrm{X}$-axis), which characterizes the equilibrium between the filtrate and the sorption liquid. The sorption liquid is enclosed in the pores of the sorbent and adsorbed on its surface. Such an experimentally found limit ratio of the

Table 1. Experimental and calculated data of the $\mathrm{pH}$ solution optimization

\begin{tabular}{|c|c|c|c|c|}
\hline $\mathrm{pH}$ & $\begin{array}{c}\text { The concentration of } \\
\text { petroleum products in the } \\
\text { filtrate, } \mathrm{mg} / \mathrm{dm}^{3}\end{array}$ & $\begin{array}{c}\text { The concentration of } \\
\text { petroleum products in the } \\
\text { sorbent, } \mathrm{mg} / \mathrm{dm}^{3}\end{array}$ & $\begin{array}{c}\text { The amount of petroleum } \\
\text { products in the sorbent, } \\
\mathrm{mg}\end{array}$ & $\begin{array}{c}\text { The efficiency of petroleum } \\
\text { products extraction, \% }\end{array}$ \\
\hline 1.65 & 21 & $31,246.3$ & 79.05 & 79.05 \\
\hline 4.01 & 19 & $32,034.8$ & 81.05 & 81.05 \\
\hline 6.86 & 18 & $32,429.1$ & 82.05 & 82.05 \\
\hline 8.12 & 17 & $32,823.3$ & 83.04 & 83.04 \\
\hline 9.18 & 18 & $32,429.1$ & 82.05 & 82.05 \\
\hline 11.34 & 19 & $32,034.8$ & 81.05 & 81.05 \\
\hline
\end{tabular}




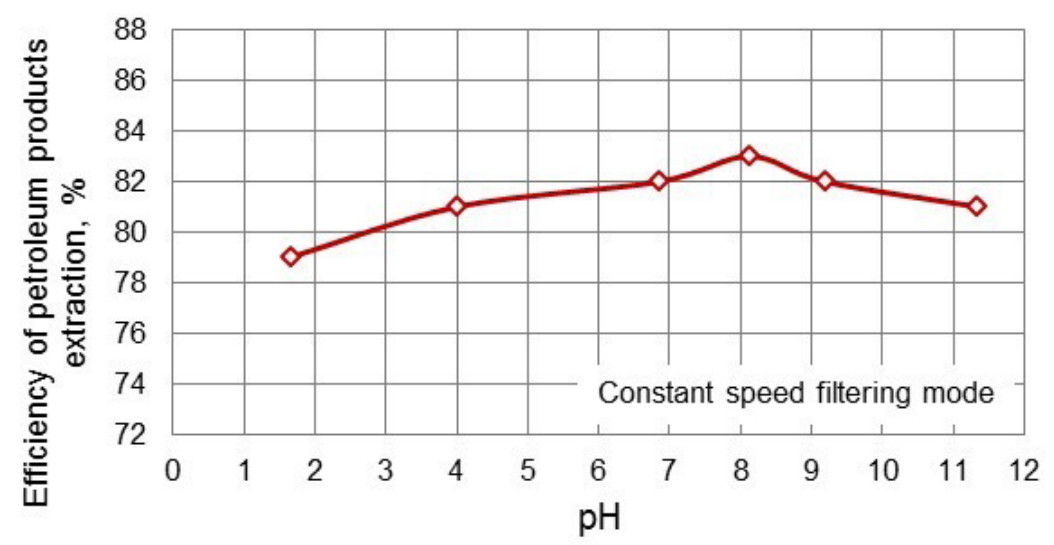

$\diamond$ Calculated efficiency

Figure 2. Dependence of the efficiency of extracting petroleum products on the $\mathrm{pH}$ value of the solution.

Table 2. Experimental and calculated data for determining the working range of water pollution with petroleum products

\begin{tabular}{|c|c|c|c|c|c|c|}
\hline $\begin{array}{c}\text { Petroleum } \\
\text { products } \\
\text { concentration in } \\
\text { the solution } C, \\
\mathrm{mg} / \mathrm{dm}^{3}\end{array}$ & $\begin{array}{l}\text { The amount } \\
\text { of petroleum } \\
\text { products in the } \\
\text { solution, mg }\end{array}$ & $\begin{array}{c}\text { Petroleum } \\
\text { products } \\
\text { concentration } \\
\text { in the filtrate } C_{f} \text {, } \\
\mathrm{mg} / \mathrm{dm}^{3}\end{array}$ & $\begin{array}{c}\text { Petroleum } \\
\text { products } \\
\text { concentration in } \\
\text { the sorbent } C_{s} \\
\mathrm{mg} / \mathrm{dm}^{3}\end{array}$ & $\begin{array}{l}\text { The amount } \\
\text { of petroleum } \\
\text { products in the } \\
\text { sorbent, mg }\end{array}$ & $\begin{array}{l}\text { The efficiency } \\
\text { of petroleum } \\
\text { products } \\
\text { extraction, \% }\end{array}$ & $C_{s} / C_{f}$ \\
\hline 0.5 & 0.5 & 0.204 & 117.20 & 0.296516 & 59.30 & 574.51 \\
\hline 1 & 1 & 0.308 & 273.83 & 0.692779 & 69.28 & 889.0448 \\
\hline 2 & 2 & 0.394 & 635.18 & 1.606997 & 80.35 & $1,612.123$ \\
\hline 3 & 3 & 0.432 & $1,015.45$ & 2.569093 & 85.64 & $2,350.583$ \\
\hline 4 & 4 & 0.488 & $1,388.63$ & 3.513235 & 87.83 & $2,845.554$ \\
\hline 5 & 5 & 0.595 & $1,741.70$ & 4.406505 & 88.13 & $2,927.23$ \\
\hline 6 & 6 & 0.708 & $2,092.41$ & 5.293791 & 88.23 & $2,955.378$ \\
\hline 7 & 7 & 0.826 & $2,441.14$ & 6.17609 & 88.23 & $2,955.378$ \\
\hline 8 & 8 & 0.944 & $2,789.88$ & 7.058388 & 88.23 & $2,955.378$ \\
\hline 9 & 9 & 1.071 & $3,135.06$ & 7.93171 & 88.13 & $2,927.23$ \\
\hline 10 & 10 & 1.19 & $3,483.40$ & 8.813011 & 88.13 & $2,927.23$ \\
\hline 20 & 20 & 2.38 & $6,966.81$ & 17.62602 & 88.13 & $2,927.23$ \\
\hline 30 & 30 & 3.6 & $10,438.38$ & 26.40911 & 88.03 & $2,899.551$ \\
\hline 40 & 40 & 4.8 & $13,917.84$ & 35.21214 & 88.03 & $2,899.551$ \\
\hline 50 & 50 & 6.05 & $17,377.59$ & 43.96531 & 87.93 & $2,872.329$ \\
\hline 60 & 60 & 7.26 & $20,853.11$ & 52.75837 & 87.93 & $2,872.329$ \\
\hline 70 & 70 & 8.54 & $24,301.03$ & 61.48161 & 87.83 & $2,845.554$ \\
\hline 80 & 80 & 9.76 & $27,772.61$ & 70.26469 & 87.83 & $2,845.554$ \\
\hline 90 & 90 & 11.07 & $31,208.70$ & 78.95801 & 87.73 & $2,819.214$ \\
\hline 100 & 100 & 12.4 & $34,636.91$ & 87.63137 & 87.63 & $2,793.299$ \\
\hline 200 & 200 & 25 & $69,194.96$ & 175.0633 & 87.53 & $2,767.798$ \\
\hline 300 & 300 & 43.2 & $101,545.18$ & 256.9093 & 85.64 & $2,350.583$ \\
\hline 400 & 400 & 79.6 & $126,719.92$ & 320.6014 & 80.15 & $1,591.959$ \\
\hline 500 & 500 & 114.5 & $152,486.04$ & 385.7897 & 77.16 & $1,331.756$ \\
\hline 600 & 600 & 172.2 & $169,263.11$ & 428.2357 & 71.37 & 982.9449 \\
\hline 700 & 700 & 277.2 & $167,391.82$ & 423.5013 & 60.50 & 603.8666 \\
\hline 800 & 800 & 404.8 & $156,610.33$ & 396.2241 & 49.53 & 386.8832 \\
\hline 900 & 900 & 591.3 & $122,607.11$ & 310.196 & 34.47 & 207.3518 \\
\hline 1000 & 1000 & 800 & $79,851.38$ & 202.024 & 20.20 & 99.81423 \\
\hline
\end{tabular}




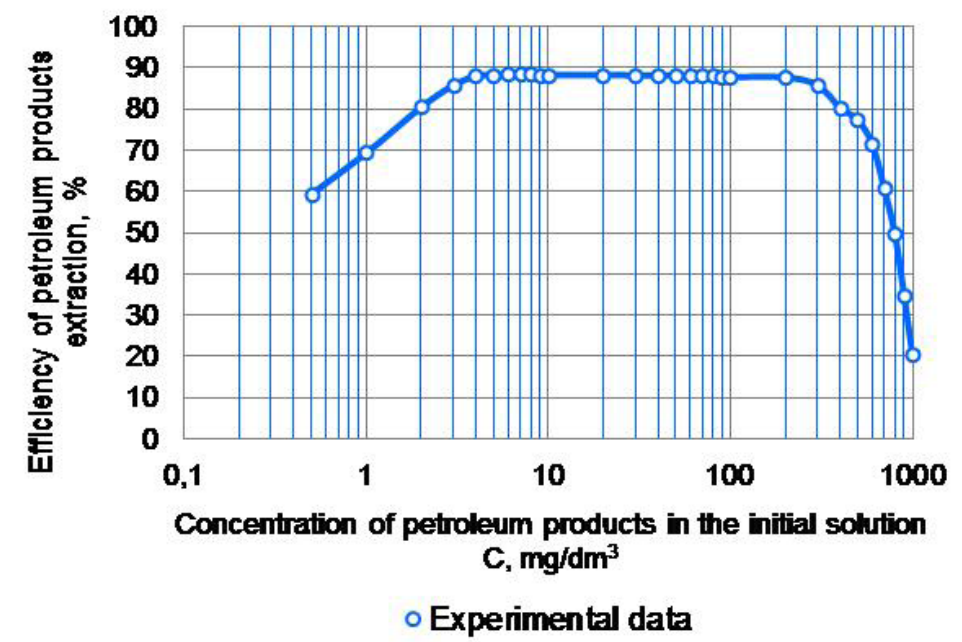

Figure 3. Dependence of the efficiency of petroleum products extraction from the solution on the concentration of petroleum products in the initial solution

concentrations determines the adsorption equilibrium constant. In this case, the adsorption equilibrium constant was $2,955.4$.

The analysis of Figure 3 shows that the removal of $85 \%$ of petroleum products from the wastewater is achieved in the contamination range between 5 and $300 \mathrm{mg} / \mathrm{dm}^{3}$. With the concentration of petroleum products in the solution $C=300 \mathrm{mg} / \mathrm{dm}^{3}$, the concentration of petroleum products in the filtrate is $C_{f}=43.2 \mathrm{mg} / \mathrm{dm}^{3}$ (Table 2). Let us check the applicability of the Henry's law for the range of petroleum products concentrations in the filtrate up to $C_{f}=50 \mathrm{mg} / \mathrm{dm}^{3}$. The Henry's law is a linear dependence in coordinates $C_{S}^{*}=f\left(C_{f}\right)$ [Keltsev, 1984].

$$
C_{s}^{*}=K C_{f}
$$

where $\tilde{N}_{S}^{*}$ is the concentration of the adsorbate in the sorbent, the equilibrium concentration of the adsorptive in the filtrate $C_{f}$, and $K$ is the Henry's law constant (the adsorption equilibrium constant).

The adsorbate and the adsorptive are petroleum products. Table 3 shows the equilibrium concentrations of adsorbate and adsorptive calculated from equation (5). The Henry's law constant is $K=2,955.4$. Figure 5 shows the comparison of the calculated and the experimental data along the $\mathrm{X}$-axis in a logarithmic system of coordinates. A good qualitative and quantitative agreement is shown for a range of petroleum products concentrations in the filtrate up to $C_{f}=50 \mathrm{mg} / \mathrm{dm}^{3}$, which confirms the known data about the applicability of the Henry's law for low concentrations of the adsorptive in the filtrate.

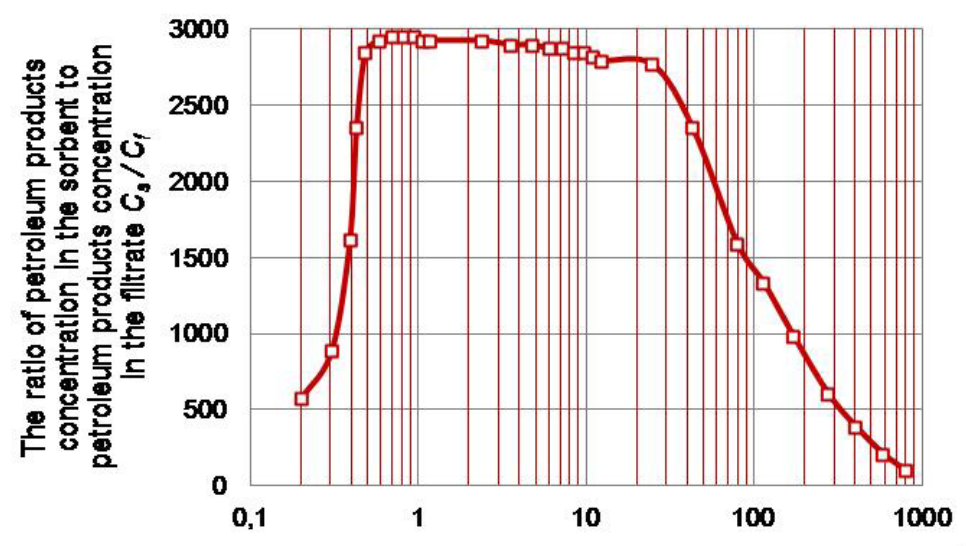

Petroleum products concentration in the fittrate $C_{f}, \mathrm{mg} / \mathrm{dm}^{3}$

Figure 4. Determination of the adsorption equilibrium constant for dynamic sorption 
Table 3. The data calculated by the Henry's law

\begin{tabular}{|c|c|}
\hline$C_{f}$ & $C_{S}^{*}$ \\
\hline 0.1 & 295.54 \\
\hline 0.2 & 591.08 \\
\hline 0.5 & $1,477.7$ \\
\hline 1 & $2,955.4$ \\
\hline 2 & $5,910.8$ \\
\hline 3 & $8,866.2$ \\
\hline 4 & $11,821.6$ \\
\hline 5 & 14,777 \\
\hline 6 & $17,732.4$ \\
\hline 7 & $20,687.8$ \\
\hline 8 & $23,643.2$ \\
\hline 9 & $26,598.6$ \\
\hline 10 & 29,554 \\
\hline 20 & 59,108 \\
\hline 30 & 88,662 \\
\hline 40 & 118,216 \\
\hline 50 & 147,770 \\
\hline 60 & 177,324 \\
\hline 70 & 206,878 \\
\hline 80 & 236,432 \\
\hline 90 & 265,986 \\
\hline 100 & 295,540 \\
\hline
\end{tabular}

In order to assess the effect of the matrix of natural fresh water on the degree of petroleum products extraction, a model solution was prepared with the content of petroleum products of $100 \mathrm{mg} / \mathrm{dm}^{3}$, including the natural compounds, the composition of which is shown in Table 4.

During the experiment, two model solutions of petroleum products in the freshwater matrix were analyzed after the treatment with the modified sorbent for preventing random measurement results. The results of the studies are shown in Table 5.

The analysis of the obtained data showed that the average degree of petroleum products extraction during the experiment was $85.5 \%$. From the data presented above, a conclusion can be drawn that the natural water matrix has an insignificant effect on the sorption of petroleum products.

\section{CONCLUSION}

The obtained experimental data show the applicability of the modified sorbent for removing the petroleum products from wastewater

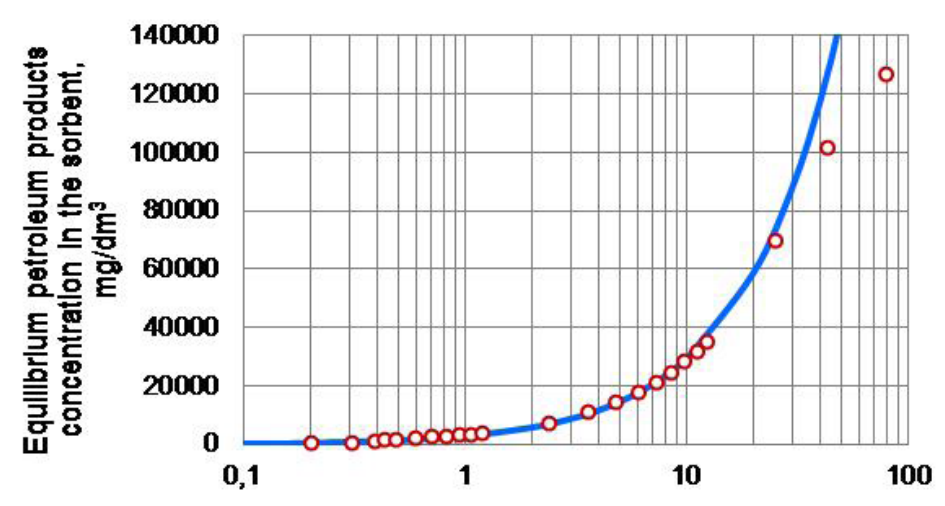

Petroleum products concentration in the fitrate, $\mathrm{mg} / \mathrm{dm}^{3}$ Calculation by the Henri's law o Experinental data

Figure 5. Comparison of the experimental to the calculated data according to the Henry's law

Table 4. Mass content of the main compounds in natural freshwater

\begin{tabular}{|c|c|c|c|c|c|c|c|c|c|}
\hline Substance & $\mathrm{NaHCO}_{3}$ & $\mathrm{MgSO}_{4}$ & $\mathrm{~K}_{2} \mathrm{HPO}_{4}$ & $\mathrm{KH}_{2} \mathrm{PO}_{4}$ & $\left(\mathrm{NH}_{4}\right)_{2} \mathrm{SO}_{4}$ & $\mathrm{NaCl}$ & $\mathrm{FeSO}_{4}$ & $\mathrm{NaNO}_{3}$ & $\mathrm{CaSO}_{4}$ \\
\hline Content, $\mathrm{mg} / \mathrm{dm}^{3}$ & 10 & 1 & 1 & 1 & 100 & 100 & 10 & 1 & 1 \\
\hline
\end{tabular}

Table 5. Determination of petroleum products concentration in model solutions with regard to the natural freshwater matrix

\begin{tabular}{|c|c|c|c|c|c|c|}
\hline $\begin{array}{c}\text { Number of } \\
\text { solution }\end{array}$ & $\begin{array}{c}\text { Eluate } \\
\text { dilution } \\
\text { factor, } \mathrm{K}\end{array}$ & $\begin{array}{c}\text { Sample } \\
\text { volume, } \mathrm{V}, \\
\mathrm{dm}^{3}\end{array}$ & $\begin{array}{c}\text { Eluate } \\
\text { volume, } \mathrm{B}, \\
\mathrm{dm}^{3}\end{array}$ & $\begin{array}{c}\text { Instrument } \\
\text { readings, } \mathrm{C}, \\
\mathrm{mg} / \mathrm{dm}^{3}\end{array}$ & $\begin{array}{c}\text { The content of } \\
\text { petroleum products in } \\
\text { the sample, } \mathrm{X}, \mathrm{mg} / \mathrm{dm}^{3}\end{array}$ & $\begin{array}{c}\text { Expanded } \\
\text { uncertainty } \pm \mathrm{U} \text { (with } \\
\mathrm{P}=.95), \mathrm{mg}_{\mathrm{dm}} \mathrm{dm}^{3}\end{array}$ \\
\hline 1 & 10 & 0.95 & 0.027 & 50.2 & 14.3 & 3.7 \\
\hline 2 & 10 & 0.95 & 0.028 & 50.0 & 14.7 & 3.8 \\
\hline
\end{tabular}


with ensuring the cleaning efficiency of at least $85 \%$ in the range of pollution between 5 and $300 \mathrm{mg} / \mathrm{dm}^{3}$. The modified sorbent was obtained from the wastes accumulated at ash dumps using the hydraulic ash disposal method and classified as hazard class V, according to the results of quantitative chemical analysis and biotesting. These wastes are inexpensive and readily-available. The disposal of ASW will result in freeing land, reducing the pressure on the natural environment, and improving the ecological situation in the adjacent urbanized areas.

\section{Acknowledgement}

This work was supported by grant No. 19-35-90074 of the Russian Foundation for Basic Research.

\section{REFERENCES}

1. Bushumov S.A., Korotkova T.G., Ksandopulo S.Ju., Solonnikova N.V., Demin V.I. 2018. Determination of the Hazard Class of Ash After Coal Combustion by the Method of Biotesting. Oriental Journal of Chemistry, 34(1), 276-285. DOI: http://dx.doi. org/10.13005/ojc/340130

2. Cherentsova A.A. 2013. Otsenka vozdeistviya zolootvalov na okruzhayushchuyu sredu (na primere Khabarovskoi TETS-3) [Assessment of the effect of ash dumps on the environment (on the example of the Khabarovsk CHPP-3)]. Diss. Candidate of Biological Sciences: 03.02.08, Ecology, Khabarovsk.

3. Cheung K.C., Venkitachalam T.H. 2000. Improving phosphate removal of sand infiltration system using alkaline fly ash. Chemosphere, 41, 243-249.

4. Dabi N. and Patwa N. 2015. Flyash: an Effective Method for Treatment of Wastewater. International Journal of Engineering Research \& Technology, $3(23), 1-3$.

5. Gorme J.B., Maniquiz M.C., Kim S.S., Son Y.G., Kim Y-T., Kim L-H. 2010. Characterization of Bottom Ash as an Adsorbent of Lead from Aqueous Solutions. Environ. Eng. Res., 15(4), 207-213.
6. Keltsev N.V. 1984. Osnovy adsorbtsionnoi tekhniki [Fundamentals of the adsorption technology]. Moscow, Chemistry.

7. Komissarenkov A.A., Fedorova O.V. 2015. Sorbtsionnye tekhnologii. Opredelenie svoistv sorbentov: uchebno-metodicheskoe posobie dlya vypolneniya kursovoi raboty [Sorption technologies. Determination of sorbents properties: a textbook for term work]. Saint Petersburg SPbGTURP.

8. Korotkova T.G., Bushumov S.A., Ksandopulo S.Yu., Istoshina N.Yu. 2018. Determination of the Hazard Class of Ash-And-Slag from a Thermal Power Plant Accumulated on Ash Dumps Under the Scheme Hydraulic Ash Removal. International Journal of Mechanical Engineering and Technology (IJMET), 9(10), 715-723.

9. Korotkova T.G., Ksandopulo S.Ju., Bushumov S.A., Burlaka S.D., Say Yu.V. 2017. Quantitative Chemical Analysis of Slag Ash of Novocherkassk State District Power Plant. Oriental Journal of Chemistry, 33(1), 186-198.

10. Makarevich N. A., Bogdanovich N. I. 2015. Teoreticheskie osnovy adsorbtcii: uchebnoe posobie [Theoretical bases of adsorption: teaching aid]. Northern (Arctic) Federal University n.a. M. V. Lomonosov. Arkhangelsk: NAFU.

11. Safaa M. Ragheb 2013. Phosphate removal from aqueous solution using slag and fly ash. HBRC Journal, 9, 270-275.

12. Shishelova T.I., Samuseva M.N., Shenkman B.M. 2008. Ispolzovanie ZSHO v kachestve sorbenta dlya ochistki stochnykh vod [The use of ash-andslag waste as an sorbent for wastewater treatment]. Modern science-intensive technologies, 5, 20-22.

13. Veprikova E.V., Tereshchenko E.A., Chesnokov N.V., Schipko M.L., Kuznetsov B.N. 2010. Osobennosti ochistki vody ot nefteproduktov s ispolzovaniem neftyanykh sorbentov, filtruyushchikh materialov i aktivnykh uglei [Particularities of water treatment from petroleum products using petroleum sorbents, filtering materials, and active charcoals]. Journal of Siberian Federal University. Chemistry, 3,. 285-304.

14. Yamada H., Kayama M., Saito K., Ham M. 1986. Fundamental research on phosphate removal by using slag, Water Res., 20, 547-557. 